\title{
The Immunization of Cattle against Rinderpest in Eighteenth-Century Europe
}

\author{
C HUYGELEN*
}

Rinderpest is caused by a morbillivirus closely related to the measles and canine distemper viruses. The pathology and symptomatology of the three diseases are very similar, ${ }^{1}$ but in terms of mortality, rinderpest is by far the most lethal; in European cattle the death rate often exceeds 80 per cent. The disease was eradicated in Europe over a hundred years ago, but in the eighteenth century an estimated 200 million cattle died from it, and the rural economy of most European countries was profoundly affected by the successive waves of epizootics. ${ }^{2}$ Many leaders of medical opinion became actively involved in the study of these outbreaks, in part out of scientific interest, but also because their assistance was requested by their respective governments. In the rural areas several medical practitioners and even clergymen took an active interest in rinderpest because they were directly confronted with the disastrous losses suffered by farmers. Cattle played a key role in rural life not only as producers of meat and milk, but also as the main source of manure. The severe losses stressed the need to have trained manpower to handle animal disease and stimulated the creation of schools of veterinary medicine in the latter part of the eighteenth and beginning of the nineteenth centuries. Most of the work on rinderpest referred to in this article was carried out by medical men and some pharmacists, none of whom had any specific training in animal diseases. ${ }^{3}$

Opinions on the cause of rinderpest have been reviewed against the background of the mainstream infectious disease concepts of those days by Lise Wilkinson. ${ }^{4}$ In spite of the lack of theoretical knowledge concerning the etiology of infectious diseases, a few

*Dr Vet. Med. C Huygelen, Vossekouter 29, B-3040 Huldenberg, Belgium.

I wish to thank Drs A H H M Mathijsen, former librarian, Faculty of Veterinary Medicine, University of Utrecht, for his invaluable help in providing most of the old Dutch publications, Prof. Dr Angela von den Driesch, Director of the Institute für Palaeoanatomie, Domestikationsforschung und Geschichte der Tiermedizin der Ludwig-MaximilianUniversität, Munich, for giving me access to her rich collection of rare German veterinary literature, and Dr G Theves, Veterinary Services, Luxembourg, for providing copies of articles from his own private collection. I should also like to thank Professor W F Bynum and the external referees for their good advice and criticism; I am also indebted to Ms Caroline Tonson-Rye for her editorial expertise.
1 Kazuya Yamanouchi, 'Comparative aspects of pathogenicity of measles, canine distemper and rinderpest viruses', Japan. J. med. Sci. Biol., 1980, 33: $41-66$.

${ }^{2}$ G R Scott, 'Rinderpest virus', in Z Dinter and B Morein (eds), Virus infections of ruminants, Amsterdam, Elsevier, 1990, p. 343.

3 Léon Moulé, 'Du rôle des médecins dans la lutte contre les épizooties au XVIIle siècle. Première partie. Peste bovine', Compt. Rendus 2e Congr. int. Hist. Méd., Paris 1921. Evreux, Ch. Hérissey, 1922, pp. 237-74. In this article the author gives a long, though still very incomplete list of the leaders of medical opinion involved in rinderpest research with brief biographies and short descriptions of their work in this field.

${ }^{4}$ Lise Wilkinson, 'Rinderpest and mainstream infectious disease concepts in the eighteenth century', Med. Hist., 1984, 28: 129-50. 


\section{The Immunization of Cattle against Rinderpest}

practical lessons had nevertheless been learned from past experience: isolation and sanitary measures, when applied strictly, had been shown to be at least partially effective in limiting the spread of human plague, and long experience with smallpox had taught that one attack of the disease would protect for life; in addition, artificial smallpox inoculation had been shown to provide protection and was becoming more popular towards the middle of the century.

Bernardino Ramazzini had been the first to describe rinderpest, in $1712 .^{5} \mathrm{He}$ was the principal professor of medicine at the University of Padua. He saw several similarities between rinderpest and smallpox and his views were widely accepted. Giovanni Maria Lancisi, the Pope's personal physician, recommended the slaughter of all infected and exposed animals. ${ }^{6}$ This policy was undoubtedly the most logical approach to combat the rinderpest epizootics, but it understandably met with much resistance and was therefore applied only sparingly especially at the beginning; later in the century it would be used successfully in several countries. In others, however, the measures were seen as too drastic and costly; in addition, their strict application required a strong central authority, which was often lacking, as in the United Dutch Provinces for example.

Against this background it was not surprising that attempts were made to apply the inoculation principle to rinderpest, as it was extrapolated to measles by Francis Home a few years later. ${ }^{7}$ Both diseases were seen as closely related to smallpox and one attack was known to provide lifelong protection. Several of the most fervent and experienced smallpox inoculators, like Pieter Camper in the Netherlands, became the most enthusiastic promotors of applying the procedure to rinderpest, especially because all attempts to cure the disease had failed; the whole range of the then known drugs used in human medicine had been tried, all to no avail. 8

\section{Initial Inoculations in England and the Netherlands}

The first written report of rinderpest inoculation was published as a letter signed "T.S." in the November 1754 issue of the Gentleman's Magazine, a journal then widely read by educated people not only in Britain, but also on the Continent. This magazine also actively supported the progress of smallpox inoculation. ${ }^{9}$ In this context it was eager to publish letters about the applications of the principle to other diseases. The author of the letter reported that a Mr Dobson, a gentleman of Yorkshire, had inoculated his cattle and had thus preserved nine out of ten of them. ${ }^{10}$ In the next issue of the journal, a correction appeared stating that Mr Dobson was very surprised to see his name mentioned in

5 Bernardino Ramazzini, De contagiosa epidemia, quae in Patavino agro, et tota fere Veneta ditione in boves irrepsit, Padua, Conzatti, 1712.

6 Giovanni Maria Lancisi, Dissertationes historicae de bovilla peste, Rome, Salvieni, 1715.

7 Francis Home, Medical facts and experiments, London, A Miller, 1759.

8 G Theves, "De la "maladie des bêtes à cornes" au Duché de Luxembourg pendant le XVIIIe siècle. Traitement et prophylaxie', Ann. Méd. vét., 1994, 138: 81-8, and Angela von den Driesch, Geschichte der Tiermedizin, Munich, Callwey, 1989, p. 180.
9 Genevieve Miller, The adoption of inoculation for smallpox in England and France, Philadelphia, University of Pennsylvania Press, 1957, p. 168. See also Roy Porter, 'Lay medical knowledge in the eighteenth century: the evidence of the Gentleman's Magazine', Med. Hist., 1985, 29: 138-68, and idem, 'Laymen, doctors and medical knowledge in the eighteenth century: the evidence of the Gentleman's Magazine', in Roy Porter (ed.), Patients and practitioners, Cambridge University Press, 1985.

10 Letter signed T.S., Gentleman's Mag., 1754, 24: 493. 


\section{Huygelen}

connection with the procedure. The letter stated that "Mr. Dobson lives in the city of York, and is so far from having any stock of cattle, that he does not even keep a cow". The real story Dobson had heard, was as follows:

Sir William St. Quintin, of Scampton in Yorkshire, inoculated eight calves, seven of which had the distemper from the inoculation, and recovered, and were afterwards turned into a herd of infected cattle, without being infected a second time; the other case was of an old ox, which was inoculated at Malton, which had the distemper from inoculation, and recovered, and was afterwards turned into a herd of infected cattle, but did not receive the infection a second time. Mr. Dobson had the foregoing account from an eminent physician in Yorkshire, who told him the method of performing the operation, and of treating the beast in distemper, which is as follows: First bleed the beast, and from that time keep him from hay, and all dry meat, till he is quite recovered; and in order to keep his body open, give him scalded bran, or chaff. At the end of three days make an incision in the dewlap, into his wound put a piece of tow, dipped in the morbid matter discharged from the nostrils, or eyes, of an infected beast, then stitch up the wound, and let the tow remain until the symptoms of distemper appear, when the tow must be taken out; after turn the beast out to grass. ${ }^{11}$

In almost all later literature on rinderpest the first inoculations have been erroneously attributed to Dobson, probably because the second letter went unnoticed; in addition, most authors misspelled his name: "Dodson". Many also gave the incorrect date of 1744 instead of 1754; few appear to have checked the original publications. Alois Kohl wrongly attributed the first rinderpest inoculations to Ramazzini in 1711, followed by "Dodson" in $1744 !^{12}$

The letters in the Gentleman's Magazine inspired Stefan Weszprémi to write his Tentamen de inoculanda peste. Weszprémi was a Hungarian physician, living in England, who saw St Quintin's experiments as proof that inoculation could be applied successfully to diseases other than smallpox, and who proposed to widen the field of application to measles and to human plague. ${ }^{13}$ As mentioned above, the first actual measles inoculations were performed by Home three years later. ${ }^{14}$

Johann Christian Polykarp Erxleben, professor at the Georg Augustus University and the Royal Institute for Historic Sciences at Göttingen, briefly mentioned some rinderpest inoculations in Brunswick in 1746 in which 9 out of 19 cattle survived, ${ }^{15}$ but $I$ have been unable to find any further details or reports on these trials, and other German authors, like Claus Dethloff von Oertzen, do not mention them at all. ${ }^{16}$

After the initial limited experiments in England, the focus of activity shifted to the Netherlands. In early 1755 funds were raised there for the purpose of purchasing cattle for an inoculation experiment, to be carried out in Beverwijk by Corneel Nozeman, Agge Roskam Kool and Jan Tak. Nozeman was a teacher in Haarlem and the two others physicians in Leiden. In the preface to their publication the authors stated that neither before nor during their experiment had they had any knowledge of the report in the

11 Letter to Mr Urban, Gentleman's Mag., 1754, 24: 549.

12 Alois Kohl, Encyklopädie der gesammten Thierheilkunde, Vienna and Leipzig, M Perles, 1891, vol. 8, p. 468.

13 Stephanus Weszprémi, Tentamen de inoculanda peste, London, J Tuach, 1755.

14 Home, op. cit., note 7 above.
15 Johann Christian Polykarp Erxleben, Praktischer Unterricht in der Vieharzneykunst, Göttingen and Gotha, J C Dieterich, 1771, p. 205-23.

16 Claus Dethloff von Oertzen, Oeffentliche Bekanntmachung der nunmehr sattsam erprobten und in Mecklenburg allgemein gewordenen Inoculation der Rindviehseuche, Hamburg, C W Meyn, 1779. 


\section{The Immunization of Cattle against Rinderpest}

Gentleman's Magazine. They described their trials in great detail: in most cases they used a thread or a wick soaked in the nasal or conjunctival secretions of infected animals; with a needle they pierced the skin between two incisions in the buttocks and left the thread under the skin; in some of their animals they used the contents of the omasum as inoculum. Of the seventeen inoculated animals only three survived and one of these had had the disease previously. In their publication the authors also mentioned another experiment that had been done by Binkhorst in Leiden; no information was given about the latter, except that he loved research; he had inoculated three one-year-old calves with secretions from a recovering animal: all three had died. The authors concluded from these disastrous results that inoculation could not be recommended; they tried to find an explanation for their failure and wondered whether it would be possible to make the operation less lethal by using a "weaker" inoculum. They referred to smallpox in which inoculators always tried to take material from patients with a mild form of the disease. They also wondered whether the disease could be made milder by adequate treatment of the inoculated animals. ${ }^{17}$

In the April 1755 issue of the Gentleman's Magazine a letter appeared on the Dutch experiments; it was signed 0.0 . The author referred to a first trial in which a young ox survived inoculation and was later shown to be immune. Thereupon the seventeen animals mentioned above were purchased and the experiment carried out as described. The investigators were not mentioned by name. ${ }^{18}$

Martinus Wilhelm Schwencke, professor of anatomy and surgery at the Hague, also sent a report to the same magazine. He referred to the trial by Nozeman and others without mentioning them, making it sound, perhaps unintentionally, as if he had done the trial himself. He then continued: "However by varying the experiment I fell at last upon a method which I think likely to answer, as far as I may judge by the success I had this summer with six young beasts of between one and two years old, all of which being inoculated at the same time, had the distemper in a mild degree and perfectly recovered from it." ${ }^{19} \mathrm{He}$ attributed his success to the use of Epsom salt. Schwencke later published the results of some further trials in $1757 .^{20}$

In a footnote to Schwencke's letter, the editor of the Gentleman's Magazine regretted that in the meantime he had received no further details of the early trial in England, and that no additional trials had been reported in his own country; he then remarked: "Upon the first appearance of our magazine in Holland, the Dutch merchants at Amsterdam instantly set on foot a subscription for the purchase of a number of cattle all of which they caused to be inoculated". 21

A few further trials were in fact performed in England. Daniel Peter Layard, Fellow of the Royal Society and at the time a medical practitioner in Huntingdon, in a letter read to the Royal Society on 2 February 1758 referred to an experiment by the Dean of York on "five

17 Corneel Nozeman, Agge Roskam Kool and Jan Tak, Eerste proefneeming over de uitwerkingen van de inentinge der besmettende ziekte in het rundvee gedaan in de Beverwijk, Amsterdam, $\mathrm{K}$ van der Sys and $\mathrm{K}$ de Veer, 1755.

18 O.O.: Letter from Amsterdam, Gentleman's Mag. 1755, 25: 160.

19 M W Schwencke, 'Letter on the subject of inoculating horned cattle', Gentleman's Mag., 1755, 25: 464 .

20 M W Schwencke, 'Proeven op het vee door inenting', Bremisches Mag. zur Ausbreitung der Wissensch., 1757, 1(47): 406, quoted by Camper, op. cit., note 31 below, p. 62 .

21 Ibid. 


\section{Huygelen}

beasts inoculated by means of a skein of cotton dipped in the matter and passed thro' a hole, like a seaton, in the dew-lap." One of them, a pregnant cow, died, but the four others survived and resisted reinfection when herded with diseased animals. A Mr Bewley, a surgeon of repute in Lincolnshire, inoculated three animals; all three recovered after a mild disease and were shown to be immune. Layard advocated inoculation, except for young calves and pregnant cows, and made detailed recommendations on how to proceed. ${ }^{22}$ Two years previously he had published a book on rinderpest in which, like most other authors, he had stressed the analogy between the disease and smallpox. ${ }^{23}$ In the meantime the epizootic had begun to recede in England and, consequently, the interest in inoculation declined. When in the 1760s the epizootic caused enormous damage on the Continent, the English government called upon Layard for advice; he recommended killing the affected animals and burying them immediately. However, he still praised inoculation as a valuable prophylactic treatment, based on his assumption that rinderpest was an eruptive fever of the variolous type. The total number of inoculations in England appears to have been very limited and after 1780 the English interest in rinderpest disappeared for nearly a century; ${ }^{24}$ almost all further experimentation was done in the Netherlands, Northern Germany and Denmark.

Independently of the above mentioned early Dutch trials, Eelko Alta, a Friesian clergyman in Boosum, had also started a trial on his own cattle in 1755, but all the inoculated animals had died. Alta was not too discouraged, because he realized that he had done his trial in a stable in which naturally infected animals were housed and that therefore no valid conclusions could be drawn from these results. He interrupted his trials for some time, but resumed them on two animals in December 1759. After blood-letting and thorough purgation, he inoculated them with a very small amount of nasal discharge from diseased cattle using a thread and a needle to perforate the skin, as he had done in his first experiment. Both animals became ill, but survived. However, when exposed to naturally infected cows, they became sick again, but less severely. Alta thought that because he had used a small amount of inoculum the animals had been unable to get rid of the virulent substance in their bodies. He published the results of his two trials in a book on rinderpest, in which he refuted the ethical and theological objections to inoculation. ${ }^{25}$

In the Netherlands, as in most other European countries, the debate for and against smallpox inoculation was very much alive in those years. The various aspects of this debate have been thoroughly reviewed by Genevieve Miller, and more specifically for France by Jean-François de Raymond and for the Netherlands by Jan Willem Buisman. ${ }^{26}$ The main arguments against inoculation were (a) medical: inoculation maintained the disease in a given area because of spread from inoculated persons to others in the neighbourhood; (b) ethical: nobody had the right to inflict intentionally a disease on

22 Daniel Peter Layard, 'A discourse on the usefulness of inoculation of the horned cattle to prevent the contagious distemper among them', Philos. Trans., 1759, 50: 11.

${ }_{23}$ Idem, Essay on the nature, causes, and cure of the contagious distemper among the horned cattle, London, Rivington, 1757.

${ }^{24}$ Charles F Mullett, 'The cattle distemper in mid-eighteenth century England', Agric. Hist., 1946, 20: $144-65$.
25 Eelko Alta, Verhandeling over de natuurlijke oorzaken der ziekte onder het rundvee, Leeuwarden, W Wigeri, 1765.

26 Miller, op. cit., note 9 above, pp. 100-33; JeanFrançois de Raymond, Querelle de l'inoculation, Paris, J Vrin, 1982, pp. 55-6; Jan Willem Buisman, Tussen vroomheid en Verlichting, Zwolle, Waanders, 1992, pp. 129-55. 
somebody else; and (c) theological: since disease was a divine punishment, trying to prevent it by inoculation was acting against God's will.

In the rinderpest debate in Holland and elsewhere, very much the same arguments were used by opponents of inoculation, with somewhat less emphasis on the ethical aspect, since animals, not people, were involved. The proponents of inoculation considered rinderpest inoculation to be medically justified since the disease had become enzootic and all cattle ran a great risk of contracting it anyway by natural infection. As far as the theological objections were concerned, Alta asked his opponents if they saw other scourges of mankind, such as floods, also as divine punishments, and if so, why they reinforced the dykes in order to prevent them.

In a postscript to his book, Alta referred to an article by Johannes Grashuis published in 1758, which he had not seen before. Grashuis was a physician in Hoorn, the author of several scientific publications and a member of a number of local and foreign learned societies. Grashuis had induced only a mild disease, but his animals were not protected, and four out of six died when exposed later to natural infection. ${ }^{27}$ Alta's conclusion from his own limited experience and that of Grashuis was that one could inoculate "too lightly" or "too heavily". He remained optimistic and thought that with adequate inoculation procedures, it would be possible to create gradually a more resistant breed of cattle, that would eventually replace the more susceptible animals: he had noticed the higher resistance of calves from so-called "gebeterde koeien", i.e. cows which had recovered from the disease. ${ }^{28}$

In the early 1760s Jan Engelman published an article on rinderpest, which is of interest because he was probably the first author to observe the close similarity between rinderpest and measles. He was a physician in Haarlem and one of the first members of the Dutch Society of Sciences there. He described in detail fifteen points of analogy between the two affections. Engelman thought that there were no solid arguments in favour of rinderpest inoculation, because it was not caused by a "pox poison"; he added however the following remark: "Suppose for a moment it was caused by a measles poison, and if one could safely inoculate against rinderpest, would this mean that one could safely inoculate this measles poison and, although no experiments in humans have been done, would one not be inclined to inoculate human beings with it, and especially children?". 29 At the time he wrote this, Engelman was obviously unaware that Home had already published his results of measles inoculation in Scotland.

\section{Further Trials in the Netherlands}

The interest in inoculation sharply increased again towards the end of the 1760 s as a result of severe losses in several parts of the country. Some of the biggest names in Dutch medicine became involved in the struggle against the epizootic, among them Pieter

\footnotetext{
27 J Grashuis, 'Berigt van de in-enting der besmettelijke ziekte onder het rund- vee', Uitgezogte Verhandelingen uit de Nieuwste Werken van de Societeiten der Wetenschappen in Europa, 1758, 3: 246-51.

${ }^{28}$ Eelko Alta, Nodige raadgevingen aan overheden en ingezetenen dewelke in het bijzonder voor den boer in deeze akelige omstandigheden,
}

\author{
waar in het vaderland zig door de ziekte van het \\ rundvee thans bevind, van zeer veel nut kunnen zijn, \\ Leeuwarden, H A de Chalmot, 1769. \\ 29 J Engelman, 'Nader verhandeling over de \\ rundveesterfte betreklijk tot de waarneemingen \\ vervat in't VI de deel, II e stuk', Verhand. Holl. \\ Maatsch. Wetenschap., 1763, 7: 247-318.
}




\section{Huygelen}

Camper, a professor at Groningen at the time. He was well known both in the Netherlands and abroad, and a member of a long list of domestic and foreign learned societies. ${ }^{30} \mathrm{He}$ was a great advocate of smallpox inoculation and had written several publications on this subject. He and his colleague Wouter van Doeveren, professor of physiology, pathology, clinical medicine and chemistry at Groningen, had come to the conclusion that rinderpest, like smallpox, would remain endemic, and that in this context, quarantine, isolation and slaughtering policies would be ineffective; prophylactic inoculation remained the only valid alternative.

In February 1769 Camper gave a series of four lectures in the Theatrum Anatomicum in Groningen. In the first three he described the anatomy of ruminant stomachs, and his fourth lecture was devoted to rinderpest; he stressed the need for inoculation trials. In the preface of his publication he stated that, at the time he started his experiments, he had been unaware of Alta's work published four years before. Camper thought that one should not be too discouraged by the negative results of early trials, because when smallpox inoculation had started in England earlier in the century, morbidity and mortality had also been high, mainly because the incisions were made too deep. With experience accumulated over the years, inoculators had learned to make very small wounds and to use minute amounts of infectious material and the results had improved significantly. ${ }^{31}$

In April 1769 Camper started a trial with van Doeveren in Groningen on 75 cows. The results published by van Doeveren, were not very encouraging: 39 animals died and 36 recovered. ${ }^{32}$ Camper himself lost interest in the Groningen trial, apparently because of its slow progress, and decided to start an experiment in Friesland, where a violent epizootic was raging. This trial was supervised by Wijnold Munniks, who would later be a professor at, and three times rector of, Groningen University, and the results were published the same year. ${ }^{33} \mathrm{~A}$ total of 112 yearlings were inoculated, of whom 45 survived. The authors found no difference between the mortality rates of those which had received an inoculum from animals that had died of the disease, and those which had been inoculated with material from animals which were recovering at the time it was taken. The surviving yearlings proved to be immune when exposed to naturally infected cattle. The authors were encouraged by their results and claimed that after natural infection only 20 to 28 animals would have survived instead of 45 . From the practical viewpoint, they recommended the use of nasal or conjunctival secretions as inoculum rather than saliva, soaking a seven to eight inch thread in it and sticking it through the skin of the buttocks or elsewhere, the inoculation site being of little importance; on the fifth or sixth day the animals were to be given a purgative.

Independently, several others performed some trials in the same period. Two medical doctors, G M Schutt and E J Römer, assisted by two surgeons, P Van Lankom and G

\footnotetext{
30 A Lange, 'Petrus Camper (1722-1789) en zijn betekenis voor de diergeneeskunde', Argos, 1990, no. 2: 27-9.

31 Pieter Camper, Lessen over de thans zweevende veesterfte openlijk gehouden ... in het Theatrum Anatomicum te Groningen, Leeuwarden, H A de Chalmot, 1769.

${ }^{32} \mathrm{~W}$ van Doeveren, 'Raadgevingen om de inentinge der ziekte van't rundvee, op eene
}

gemakkelijke, onkostbare en voordeelige manier te doen', in Eduard Sandifort (ed.), Natuur- en Geneeskundige Bibliotheek, s'Gravenhage, P van Cleef, 1769, vol. 6, pp. 436-42.

33 Petrus Camper and Wynold Munniks, Voorloper van waarneemingen omtrent den uitslag van de inëntinge der besmettelijke veeziekte, Leeuwarden, H A de Chalmot, 1769. 


\section{The Immunization of Cattle against Rinderpest}

Greeve, obtained disastrous results in five experiments in the province of Utrecht. When they heard of Camper's experiments, they published an open letter to him reporting their data in detail. ${ }^{34}$ Johan Spruit, a surgeon, also carried out a few experiments with variable results. ${ }^{35}$ In June 1769 Johannes de Vries, a provincial surgeon in Leeuwarden, started inoculation trials in Langweer at the request of the authorities; his results were disastrous: 39 out of 53 inoculated animals died, but he had apparently been experimenting in a contaminated environment. In various experiments performed in Friesland between November 1769 and January 1770 a total of 330 animals were inoculated and 156 of them recovered. ${ }^{36}$ Faced with all these negative results, with both inoculation and various other types of treatment, the Friesian authorities concluded in November 1769 that the cause of rinderpest was God's displeasure with the sinful behaviour of the Friesian people, and 15 November was proclaimed a day of prayer and fasting.

As a direct consequence of the negative results recorded in different parts of the country, the interest in rinderpest inoculation declined sharply in the Netherlands. Henricus Vink, professor of anatomy and surgery at the Rotterdam Medical School, gave a series of lectures in Rotterdam in October 1769; he was opposed to inoculation and strongly disagreed with Camper and Munniks. The latter had claimed that even if the postinoculation losses were high, the farmers gained by it, because the recovered animals fetched a much higher price. This led to fraud, however, and quite a few fully susceptible cows were sold as having recovered. Vink also questioned the calculations made by Camper and Munniks on the comparative mortality rates of inoculated animals versus those which would have succumbed if exposed to natural infection, claiming that under natural conditions 100 per cent of the animals would in no circumstances have been infected. ${ }^{37}$

\section{Reinders' Experiments in the Netherlands}

In this climate of discouragement and scepticism, Geert Reinders, a farmer in the province of Groningen and a self-taught man, decided to continue the experiments. ${ }^{38} \mathrm{He}$ contacted Camper, and in collaboration with Munniks, carried out several trials with variable success in the $1769-1770$ period. In some cases the mortality rate after inoculation was extremely high, in others the animals did not become resistant to subsequent infection, or developed severe local infections at the inoculation site. The authors tried different inoculation procedures and a variety of treatments to alleviate the symptoms, all of them without any measurable effect. Out of the 150 inoculated cattle 86

\footnotetext{
34 G J Schutt, E J Römer, P van Lanckom and G Greeve, Brief aan den Hoog Geleerden Heere Petrus Camper behelzende eenige proeven omtrent de inëntinge der besmettelijke veeziekte, genomen in de Vrijheid van Utrecht, Utrecht, G B Timon van Paddenburg, 1770.

35 Johan Spruit, 'Brief van den Heer Joh. Spruit, Heelmeester te Nichtwegt, aan den Schrijver, behelzende eenige waarneemingen over de inenting van de ziekte der runderen', in Sandifort, op. cit., note 32 above, p. 899.

$36 \mathrm{~J}$ de Vries, 'De bestrijding van de runderpest in
}

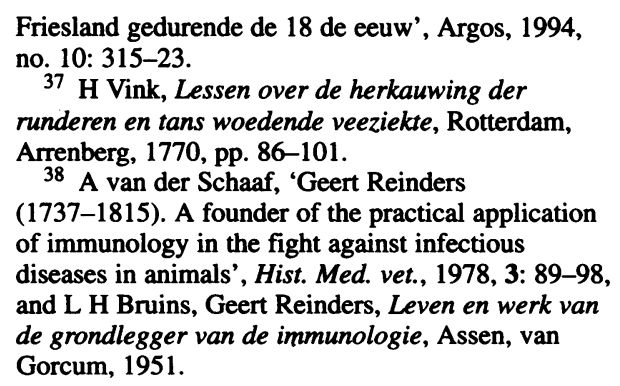
of immunology in the fight against infectious diseases in animals', Hist. Med. vet., 1978, 3: 89-98, and L H Bruins, Geert Reinders, Leven en werk van de grondlegger van de immunologie, Assen, van Gorcum, 1951. 


\section{Huygelen}

recovered and 64 died. They reached three conclusions from their work: (a) infectious material taken from a diseased animal on the second, third or fourth day of sickness, always produced rinderpest; (b) inoculated animals which had shown typical symptoms, were always immune to reinfection even when the symptoms had been mild; and (c) the mode of inoculation and the various therapies used had no impact on the results.

Reinders resumed his experiments in 1774, concentrating on the inoculation of calves from cows that had recovered from rinderpest. He was in all probability the first to make practical use of maternally derived immunity. In rinderpest most, but not all, calves lose their colostrum derived antibodies by the age of nine to ten months; some lose theirs at a much earlier age. ${ }^{39}$ As for other morbillivirus diseases, there is great individual variation related directly to the antibody titres of the individual mothers.

In an open letter to Camper and Munniks, Reinders reported his observation that calves from immune dams did not become susceptible to the contagion before they were put out in the open air in the spring. He had discussed this phenomenon with them several times between 1769 and 1774, but had not been able to generate much interest on their part. He had therefore decided to embark upon trials on his own and had inoculated calves from cows which had had the disease five years previously; the calves had been inoculated when six to eight weeks old and while still indoors; they had shown only very mild reactions. Some of them had been reinoculated after they had been out in the pastures for four to five weeks and had shown some very mild symptoms on the sixth day after inoculation; they were later shown to be resistant to natural infection. Reinders invited Camper and Munniks to repeat his experiments. ${ }^{40}$ The detailed results of his trials were published in 1776 and reprinted in 1777 together with his 1774 letter to Camper and Munniks. ${ }^{41}$ Reinders had gone through a difficult time while carrying out these trials: he had been attacked by zealots who accused him of atheism because he acted against God's will.

Although Alta had briefly referred to the higher resistance of calves from recovered cows, he had attributed it to a kind of hereditary resistance. Reinders came much closer to the true explanation with his observation that the resistance of the calf depended only on the immune status of the dam and was not influenced by that of the bull. He had also noticed that once a cow had recovered from the disease, all the calves she bore afterwards were initially resistant, irrespective of the time since her recovery. He also noticed that, after having spent half a year in the open air, these calves became as susceptible as calves from non-immune dams. Since virtually all calves were born in the early part of the year, they would have lost their maternally derived immunity and become susceptible towards the end of the summer. Initially, Reinders had wrongly attributed this decline of resistance to exposure to the open air, but he soon realized that this factor was unrelated. ${ }^{42}$

${ }^{39} \mathrm{R}$ D Brown, 'Rinderpest immunity in calves-a review', Bull. epizoot. Dis. Afr. 1958, 6: 127-33; W Plowright, 'Rinderpest virus', in S Gard, C Hallauer and K F Meyer (eds), Virology Monographs No. 3, Vienna and New York, Springer, 1968.

40 Geert Reinders, Brief aan den Wel Edelen Hooggeleerden Heere Petrus Camper en aan ... Wyn. Munnicks weegens eene voorname ontdekkinge door inentinge op het rundvee gedaan, Groningen, L Huisingh, 1774.
41 Idem, Waarneemingen en proeven meest door inëntinge op het rundvee gedaan, dienende ten bewijze, dat wij onze kalvers van gebeterde koejen geboren, door inëntinge tegen de veepest kunnen beveiligen, Groningen, L Huisingh, 1776 (reprinted 1777).

42 Interference of maternally derived antibodies with active immunization using parenterally administered live attenuated virus vaccines is a well known problem today, especially in measles and 


\section{The Immunization of Cattle against Rinderpest}

Reinders found out that in order to increase his chances of success, he had to inoculate the calves two or three times at different ages. He predicted, rather optimistically, that with his method of repeated inoculations, a resistant cattle population could be created, not only in his own country, but throughout Europe. The main problem he foresaw, was the supply of enough infectious matter to keep inoculating.

His inoculation procedure did not differ much from what had been used previously: infectious material was obtained from nasal discharge on the second to fourth day of illness, a thread was soaked in it and then with a needle drawn through a fold of loose skin, usually in the buttocks; the thread was removed 4 to 5 days later. He recommended three inoculations routinely: the first one in the stable, preferably at the age of six weeks, the second when the calves had been outdoors for three or four weeks and the third in August or September. Reinders' chances of success may have been greatly increased because of unintentional contact of the inoculum with the nasal and oral mucosae of the calves through licking of the wounds or otherwise.

Reinders' example was followed by Jan Hendrick Stolte, a local physician in Zwolle, using 120 calves from immune dams: 20 of them died, but 4 of these were presumed by the author to have succumbed to an intercurrent disease; of the other 100 animals 48 were inoculated a second and a third time without showing signs of illness. ${ }^{43}$

The publication of Reinders' work generated renewed interest in inoculation, because his results were much better than those obtained previously in other cattle. ${ }^{44}$ In 1780 the Amsterdamsche Maatschappij ter Bevordering van den Landbouw (Amsterdam Society for the Advancement of Agriculture), published the results of a survey: 1,829 inoculated animals had survived, i.e. 90 per cent. ${ }^{45}$ The total figures for the period 1777 to 1781 showed 3,373 survivors out of 3,796 inoculated animals, i.e. 89 per cent. ${ }^{46}$ These figures compared very favourably with the survival rate after natural infection in the 1769-1776 period, i.e. only 126,307 out of $438,045,29$ per cent. In 1784 more than half the calves born in some parts of Friesland were inoculated. ${ }^{47}$

Judging from a publication in 1778, Reinders' trials appear to have been well organized: in this document he stipulated the "Conditions under which the Inoculation Society, established at Garnwert, proposes to supply calves which have recovered from

canine distemper. The young cannot be immunized as long as the antibodies have not declined below a certain threshold; the age at which this threshold is reached is entirely dependent on the initial titre, which in turn depends on the titre of the mother; this leads to wide individual variation in the ages at which infants or young animals can be successfully immunized. The problem can be partially overcome by increasing the number of vaccinations, thus enhancing the chances of injecting the vaccine at a time when the antibodies have sufficiently declined. Another possible approach is to administer the vaccine via the nasal mucosa, but this approach is greatly hampered by the decreased tropism of attenuated measles and distemper viruses for this mucosa. In rinderpest Brown demonstrated in 1958 (op. cit., note 39 above) that after parenteral inoculation of live caprinised (= goat-adapted) virus all calves with a neutralizing antibody titre of $10^{0.7}$ or less responded actively; those with titres of $10^{0.7}$ to $10^{2.2}$ could sometimes be infected, sometimes not.

43 Johan Hendrick Stolte, Schreiben wegen

Einimpfung des jungen Rindviehes, dated 1 November 1777 and published with Schumacher's book, see note 53 below.

44 Geert Reinders, Bericht uit Holland, Friesland en de provintie van Stad en Lande, wegens de inenting der kalveren van gebeterde koejen voor den jaare 1776, Groningen, L Huisingh, 1777.

45 Eelko Alta, 'Bericht van de inënting der kalveren', Verhand. Maatsch. ter bevordering van den Landbouw, Amsterdam, 1780, 2 (1ste stuk): 125-64.

46 J M G van der Poel, Heren en Boeren, Wageningen, Veenman, 1949.

47 Van der Schaaf, op. cit., note 38 above. 


\section{Huygelen}

the disease versus non-immune ('ongebeterde') calves". Not only were the financial conditions clearly spelled out, but also the required age and other specifications. ${ }^{48}$

Reinders' results were summarized by Camper in a paper to the Société Royale de Médecine in Paris, but no reference was made to Reinders. ${ }^{49}$ According to Camper, apart from secretions, meat, blood or a piece of skin could also be used as inoculum. He also presented a lengthy paper to the Berlin Gesellschaft Naturforschender Freunde, again without giving due credit to Reinders. ${ }^{50}$ Camper made a plea for generalized immunization and recommended to governments the creation and maintenance at their expense of non-immune herds to serve as a reservoir for the production of the inoculum. His recommendations met with little success in the majority of European countries because they were already applying the eradication method.

In the Netherlands the interest in rinderpest inoculation declined in the 1780s because the epizootic itself decreased in intensity. When it reappeared in 1797 in Gelderland, Rudolph Forsten, a professor of medicine at Harderwijk, recommended inoculation under certain conditions, but stated in the same article that killing affected animals could be very efficient, as shown by the results in other countries. ${ }^{51}$

\section{Inoculation in Other Countries}

Apart from the United Dutch Provinces, Northern Germany and Denmark were the only other regions where inoculation was used to any significant level. The situation in 1779 was reviewed in detail by Claus Dethloff von Oertzen ${ }^{52}$ and by W Schumacher. ${ }^{53}$ The former was "Oberhauptmann" in the dukedom of Mecklenburg-Schwerin; the latter was also an officer in the same dukedom and member of the Königliche Grossbrittanische Landwirtschaftsgesellschaft (Royal British Agricultural Association) in Celle. Von Oerzen quotes extensively an anonymous article published in Brunswick in 1763, in which inoculation was advocated because, even if the losses were high, the quarantine period could be much shortened because all animals would go through the disease at the same time, whereas in a naturally occurring epizootic these measures had to remain in place for several months. ${ }^{54}$

During the epizootic of the late 1770s Mecklenburg became the focus of inoculation experiments in Germany. The trials started on a large estate owned by Herr von Bülow, Royal Danish Kammerjunker, after the rinderpest invasion of 1776 . On some farms the

\footnotetext{
48 Geert Reinders, Conditien op welke de Inëntings Societeit, te Garnwert opgeregt, presenteert, kalveren welke van de besmettelijke veeziekte zijn gebeterd, te leveren, tegens ongebeterde kalvers, Garnwert, 16 June 1778 (published as a supplement to his earlier book, see note 41 above).

49 Petrus Camper, 'Mémoire sur l'épizootie de la Hollande', Soc. roy. Méd., 12 Aug. 1777.

50 Petrus Camper, 'Ueber die wahre und eigentliche Ursache der Krankheiten, die unter dem grossen und kleinen Viehe als ansteckende Seuchen, wüthen', Beschäft. d. Berlinischen Gesellsch. Naturforsch. Freunde, 1779, 4: 95-166.

$51 \mathrm{R}$ Forsten, De vee-pest welke zich in het
}

Quartier van Nymegen geopenbaart heeft . . war war bij gevoegd is voorbehoed en geneeskundig advys over dezelve vee-pest, uitgebragt door de Geneeskundige Faculteit te Harderwyk, Arnhem, van Goor, 1797.

52 Von Oertzen, op. cit., note 16 above.

53 W Schumacher, Die sichersten Mittel wider die Gefahr beym Eintritte der Rindvieseuche aus Erfahrungen und Urkunden bestätiget 1777, 2nd ed. Berlin, Oemigke, 1793.

54 Anon., Versuch einer nähern Erklaerung der Hornviehseuche nebst einigen Wahrnehmungen über die Einpropfung derselben, Braunschweig, 1763 (quoted by von Oertzen, op. cit., note 16 above). 


\section{The Immunization of Cattle against Rinderpest}

disease was associated with relatively low mortality and neighbours brought their cattle to these farms to be infected with this "mild" form. Von Bülow started doing inoculation trials in 1777 using this benign inoculum. In the first experiments the mortality was high, but von Bülow persevered and in one of the subsequent trials 22 of 25 cattle survived. He continued his trials in 1778 and also observed that calves from immune dams reacted only slightly or not at all, even when they were inoculated three times. He was probably aware of the Dutch experience.

Von Oertzen attributed the relatively favourable results obtained by von Bülow to the benign nature of the infection; the inoculated animals became sick on only the ninth or tenth day instead of the fifth day when inoculated with more virulent material. A total of 135 out of the 177 cattle inoculated by von Bülow had survived when von Oertzen started his own experiment with "benign" material, and generally, but not always, with good results.

Inoculations became more and more generalized in Mecklenburg and "insurance companies" were created which provided inoculation in special "institutes" on the following conditions: the owners were invited to estimate the value of their cattle; the animals were then placed in inoculation stables and inoculated; if an animal died the owner received the estimated price as compensation; if it survived, the farmer had to pay half the value before he received it back after recovery. Von Oertzen mentioned that at the time he was writing his book, the "insurance companies" had already reduced their price to one third of the value. According to Worseck the inoculation institutes in Mecklenburg were private initiatives created with full encouragement from the authorities. ${ }^{55}$

Both von Oertzen and Schumacher described in detail the procedures to be used for inoculation. These corresponded roughly to those used in the Netherlands, but von Oertzen insisted in particular on the choice of a benign inoculum. Pregnant cows and calves under six months were excluded. Between 15 and 40 healthy cattle were brought together in the inoculation stables and usually inoculated by an incision in the upper part of the flank; threads infected with nasal secretions were laid in the wound, which was then covered with a plaster; care was taken to prevent the animals from licking the wound; the threads were removed on the sixth day.

Storage of the inoculum was a problem: in summer it could not be held for more than an average of five or six days, in winter two weeks; von Oertzen wrapped the infected cotton or linen threads up in wax paper and put them in an apothecary's box. Schumacher recommended burying them in a dry place in the ground.

A survey in Mecklenburg on the mortality post inoculation demonstrated that the overall results were good, even when the less successful experiments were included. In total 3,241 of 4,075 inoculated cattle fully recovered; 438 died and 290 were still sick at the time of the survey, but 106 of them only slightly. ${ }^{56}$ Apart from von Bülow and von Oertzen, Jacob Brackenwagen also carried out several successful trials. He was a farmer on royal estates in Glambeck. ${ }^{57}$ Schumacher's book contains several practical recommendations and contributions by Brackenwagen. ${ }^{58}$

\footnotetext{
$55 \mathrm{M}$ Worseck, 'Die Bekämpfung der Rinderpest vor 200 Jahren in Mecklenburg', Mh. Vet. Med. 1977, 32: $182-4$.

56 Von Oertzen, op. cit., note 16 above.
}

57 H Kilian, 'Die Bekämpfung der Rinderpest in Mecklenburg-Strelitz (1769- 1780)', Inaugural Dissertation Veterinary Medicine, Berlin, 1934.

58 Schumacher, op. cit., note 53 above. 


\section{Huygelen}

The Mecklenburg experience with inoculation stables was watched with interest by neigbouring states: Prussia authorized some experiments in the years 1779-1781, but inoculation apparently never became widespread there. ${ }^{59}$ In a series of articles in a local magazine in Hanover inoculation was promoted and an appeal made to create a stateowned inoculation institute. ${ }^{60}$ In 1779 , J A Kersting, a veterinarian at the Hanover Veterinary School, which had been created the year before, was sent on an official mission to Gartau to study the procedures used in Mecklenburg. He wrote a detailed report which was published after his death. ${ }^{61}$ During his stay 135 animals were inoculated of which 7 died. In his recommendations, which followed closely those of von Oertzen and Schumacher, Kersting insisted on taking the nasal secretions of the individual animals separately, on noting carefully the name or the number of the donor animal and on always using material from an animal that had shown mild symptoms; he also stressed the importance of using only animals in good health for the propagation of the inoculum. Overall, the losses in the inoculation institutes in Mecklenburg did not exceed 10 per cent. $^{62}$

In the German-speaking countries many remained opposed to inoculation. Johann Gottlieb Wolstein was against it; he was a professor and director of the Animal Hospital in Vienna and founder of the Vienna Veterinary School; he was also opposed to slaughtering but did not come up with a clear viable alternative. ${ }^{63}$ Others claimed that there was no difference between benign and severe epizootics and that the whole outcome depended on the circumstances and on the constitution of individual animals.

Rinderpest had virtually disappeared from Mecklenburg by 1792 when Schumacher wrote the preface to the second edition of his work; he thought it useful to re-edit his recommendations, however, since the epizootic was still raging in other regions. ${ }^{64}$ During the Franco-German wars at the end of the century rinderpest reinvaded Germany but little use was then made of inoculation. It could only be applied by special permission. ${ }^{65}$ Gottfried Christian Reich, professor of pharmacy at Erlangen, was probably one of the last advocates of inoculation. In his own experiment almost all the inoculated animals survived. 66

In Denmark a first series of inoculation experiments was done at royal expense in the years 1770 to 1772 and reported in detail by Johann Clemens Tode, a doctor of pharmacy and professor at the University of Copenhagen; most trials were done on the island of Avnöe. ${ }^{67}$ In the first year 61 animals were inoculated, most of which succumbed to the infection; in 1771160 were inoculated, of which 91 became infected, one died, and 68 did

59 W Dieckerhoff, Geschichte der Rinderpest und ihrer Literatur. Beitrag zur Geschichte der vergleichenden Pathologie, Berlin, Enslin, 1890.

60 H M Wens, 'Beitrag zu der Inoculation der Rinderpest nach den Anweisungen von J.A. Kersting in den Jahren 1779 bis 1781', Dtsch. tierärztl. Wschr, 1987, 94: 559-62.

61 Günther jun, 'Kersting, über die Einimpfung der Rinderpest', Mag. f. die ges. Thierheilk., 1858, 24: $1-42$.

62 Schumacher, op. cit., note 53 above.

63 Johann Gottlieb Wolstein, Anmerkungen über die Viehseuchen in Oesterreich nebst einer Abhandlung gegen das Umbringen der Thiere in
Seuchen, Vienna, J E von Kurzbeck, 1782.

64 Schumacher, op. cit., note 53 above.

65 J J Kausch, Kameralprinzipien über Rindviehsterben, Berlin, 1793 (quoted by Dieckerhoff, op. cit., note 59 above).

66 Gottfried Christian Reich, Richtige und gewissenhafte Belehrung für den Landmann über die Rindviehseuche und die Inoculation derselben, Nürnberg, Raspesche Buchhandlung, 1797.

67 Johann Clemens Tode, Geschichte der Einimpfungen der Hornviehseuchen welche in den Jahren 1770, 71 und 72 in Dänemark auf königliche. Kosten angestellet worden, Copenhagen, Rothen, 1775. 
not show any symptoms; in 1772169 animals were inoculated, 123 of them recovered, 2 died and 44 showed no signs of disease. Extensive trials were started in 1777 under the supervision of Peter Christian Abildgaard, later Dean of the Copenhagen Veterinary School. ${ }^{68}$ Out of 1199 inoculated cattle 38 remained healthy, 580 became ill and recovered, and 581 died. His results corresponded roughly to those reported by Camper in the Netherlands.

In Sweden inoculation was strongly opposed by the well-known scientist Peter Jonas Bergius, a botanist and doctor of medicine, and professor of natural history at Stockholm, who claimed that rinderpest was similar to human plague; since plague could infect a human being several times over, it would be impossible to protect cattle by inoculation. ${ }^{69}$ In France, Félix Vicq d'Azyr, who became very actively involved in the struggle against rinderpest, carried out a trial, but almost all the inoculated animals died. ${ }^{70}$ In the majority of European countries the struggle against the disease was based upon stamping it out, sometimes with minimal losses, in other cases with heavy sacrifices. This method was applied successfully in, for example, England and the Austrian Netherlands (roughly today's Belgium). ${ }^{71}$

In the nineteenth century rinderpest inoculation was no longer practised in Western or Central Europe, but for several decades it remained popular in parts of Russia. ${ }^{72}$

\section{Conclusions and Comments}

Inoculation was not a valid solution to the immense problem created by the rinderpest invasion of Europe in the eighteenth century. Not only were the losses after inoculation in many instances too high, but, even more importantly, the procedure perpetuated the circulation of the causal agent in the cattle population. From the scientific point of view, however, the inoculation pioneers made some significant contributions to our knowledge in those very early days of active immunization against infectious diseases.

The rinderpest experience proved that smallpox was not unique in being preventable by inoculation and that the procedure provided lifelong protection. It confirmed the concepts of those who saw infectious diseases as caused by specific etiological agents; in this context Camper's statement sounded very modern when he wrote

that each kind of contagious epizootic in cattle comes from a specific germ or material, which always causes the same attacks of disease and that this matter is spread everywhere by the air as a general vehicle and through inhalation to the lungs, sometimes also with the nasal mucus or with the saliva, or with the intake of food, it is brought into the body and mixes with the blood. ${ }^{73}$

68 Peter Christian Abildgaard, 'Abhandlung über die allgemeine Rindviehseuche in vorzüglicher Hinsicht auf ihre Einfälle in Dänemark und die daselbst angestellten Impfversuche' in Erich Viborg, Sammlung von Abhandlungen für Thierärzte und Oekonomen, vol. 1, Copenhagen, Prost, 1795.

69 Peter Jonas Bergius, Bedenklichkeiten bei der Einimpfung der Hornviehseuche Göttingen, 1772 (quoted by Dieckerhoff, op. cit., note 59 above).

70 Félix Vicq d'Azyr, Exposé des moyens curatifs et préservatifs qui peuvent etre employés contre les maladies pestilentielles des bêtes à cornes, Paris, Mérigot, 1776.

$71 \mathrm{R}$ De Herdt, Bijdrage tot de geschiedenis van de veeteelt in Vlaanderen, inzonderheid tot de geschiedenis van de rundveepest 1769-1785, Leuven and Ghent, Belgisch Centrum voor de Landelijke Geschiedenis, 1970.

72 Peter Jessen, Ueber die gänzliche Ausrottung der Rinderpest, Dorpat, H Laakmann, 1852.

73 Camper, op. cit., note 50 above. 


\section{Huygelen}

The observation by Reinders and Stolte, that calves from recovered cows were resistant represented probably the first recognition in any species of the phenomenon of maternally derived immunity. Reinders noticed that this resistance was not of hereditary origin, that it depended solely on the immunity of the dam, that it subsided with the increasing age of the calf and that this happened much earlier in some calves than in others; he also noticed that the immunity gradually disappeared leaving the calves just as susceptible as those from dams who had not had the disease. He took advantage of this temporary resistance to inoculate calves with minimal risk and he realized that he increased his chances of successful inoculation by repeating the procedure at different ages, because in some of the calves the first inoculation would not produce a "take".

It is interesting to note that for two morbillivirus infections the same procedures would be "reinvented" a century and a half later. In 1915 Charles Herrman, Attending Paediatrician to the Lebanon Hospital in New York, tried to develop a practical immunization method against measles by inoculating a naturally occurring virus into infants with maternally derived immunity, ${ }^{74}$ and in 1924 Doutresoulle, a French veterinary surgeon in Niger, inoculated rinderpest in calves from immune dams. ${ }^{75}$ Neither method had any widespread application because of the wide variation in immune status of the individual infant or calf.

Naturally occurring rinderpest virus strains are known to have a variable degree of virulence. ${ }^{76}$ The Mecklenburg investigators apparently used this phenomenon with some success by systematically selecting less virulent material in their inoculation institutes. Also, as a rule, they used material derived from previously inoculated animals. The total number of passages, however, probably remained very limited and it seems unlikely that this would have resulted in any significant further attenuation of the virus, as suggested by Wens. ${ }^{77}$

The idea of inoculation against rinderpest and later against measles, was based upon the presumed similarity of these diseases with smallpox; in the latter disease inoculation in most cases would produce a skin eruption and, relatively speaking, less involvement of the respiratory tract and, hence, much less morbidity and mortality than in natural disease. It was hoped that for rinderpest and measles a similar strategy could be developed, but morbilliviruses behave in a very different way from poxviruses and in spite of many attempts the dermal inoculation principle has never found any general application for either of these two diseases. ${ }^{78}$ For both of them reliable attenuated virus vaccines did not become available before the second half of the twentieth century.

\footnotetext{
74 Charles Herrman, 'Immunization against measles', Arch. Pediatr., 1915, 32: 503-7.

75 Doutresoulle, 'Rapport sur la recherche d'une méthode d'immunisation active des veaux non sevrés, provenant de mères réfractaires à la peste bovine', Rec. Méd. vét., 1924, 100: 464-8.

76 Scott, op. cit., note 2 above.
}

\footnotetext{
77 Wens, op. cit., note 60 above.

$78 \mathrm{C}$ Huygelen, 'The long prehistory of modern measles vaccination', in S A Plotkin and B Fantini (eds), Vaccinia, vaccination, vaccinology, International Meeting on the History of Vaccinology, Marnes-la-Coquette, 6-8 Dec., 1995, Amsterdam, Elsevier, 1996, pp. 257-63.
} 